\title{
INTERSTITIAL WATER PATTERNS: A FACTOR INFLUENCING THE DISTRIBUTIONS OF SOME LOTIC AQUATIC VASCULAR MACROPHYTES
}

\author{
SHARON L. FORTNER and DAVID S. WHITE ${ }^{1}$ \\ Great Lakes Research Division, Program in Water Resource Science and Biological Station, \\ University of Michigan, Ann Arbor, MI 48109 (U.S.A.)
}

(Accepted for publication 15 February 1988)

\section{ABSTRACT}

Fortner, S.L. and White, D.S., 1988. Interstitial water patterns: a factor influencing the distributions of some lotic aquatic vascular macrophytes. Aquat. Bot., 31: 1-12.

The distributions of 9 species of aquatic vascular macrophytes were examined in relation to interstitial water patterns (based on temperature) in the beds of three northern Michigan (U.S.A.) streams. Ranunculus septentrionalis Poir., Caltha palustris L. and Nasturtium officinale R.Br. were associated with areas of groundwater discharge. Sparganium chlorocarpum Rydb., Veronica catenata Penn., Potamogeton filiformis Pers. and P. richardsonii (Benn.) Rydb. occurred most often at the downstream end of a hyporheic zone (corresponding to the foot of a riffle) where interstitial water was of surface origin. Sagittaria latifolia Willd. occurred where interstitial temperatures were cool; the water origin was not determined. Potamogeton gramineus L. occurred most often where interstitial temperatures were warm, primarily at the upstream ends and middles of hyporheic zones (heads of riffles) in areas of surface-water infiltration. Complex patterns of interstitial water movement and related physicochemical complexity combined with differences in plant requirements, in part, may determine observed local distributions.

\section{INTRODUCTION}

Factors known to control the distribution and growth of lotic aquatic macrophytes include turbulence, light, surface-water chemistry, surface-water temperature, flow, sediment structure and chemistry, and other biota (Spence, 1967; Peltier and Welch, 1968; Kullberg, 1974; Hutchinson, 1975; Beal 1977; Haslam, 1978). Although often implied in habitat descriptions for lotic species (Muenscher, 1944; Fassett, 1969; Correll and Correll, 1972) or in general descriptions of lotic systems (Gray et al., 1983) the influence of interstitial water has received much less attention.

\footnotetext{
${ }^{1}$ Author to whom correspondence should be addressed: Benthos Laboratory, 1061 North University Building, University of Michigan, Ann Arbor, Michigan 48109, U.S.A.
} 
Interstitial water can be divided roughly into the categories of infiltrating surface water, underflow or hyporheic water, and groundwater based on primary origin of the water and flow patterns within the bed (Fig. 1). The boundaries between water types, however, are rarely distinct and more often are represented by vertical physicochemical gradients from surface water to groundwater. The depths of the gradients will be dependent on stream flow, bed permeability and changes in streambed elevation (Vaux, 1968; Thibodeaux and Boyle, 1987; White et al., 1987). Decreasing stream depth along the direction of flow (such as at the head of a riffle) causes surface water to enter the bed (infiltration), displacing existing interstitial water, and travel for some distance through the bed as underflow. Underflow then returns to the surface where stream depth begins to increase (Fig. 1). Interactions between surface water infiltration and bed sediments along underflow paths promote solute storage, creating sinks for nutrients and even very conservative ions (Wallis et al., 1981; Bencala, 1984; Grimm and Fisher, 1984), with the result that underflow areas, or hyporheic zones, often contain much higher concentrations of organic matter, phosphorus, nitrogen, ions, etc. than either the original surface water or the groundwater beneath.

The direct movement of groundwater into surface sources may occur in the form of distinct springs (often the source of first-order streams, Wisler and

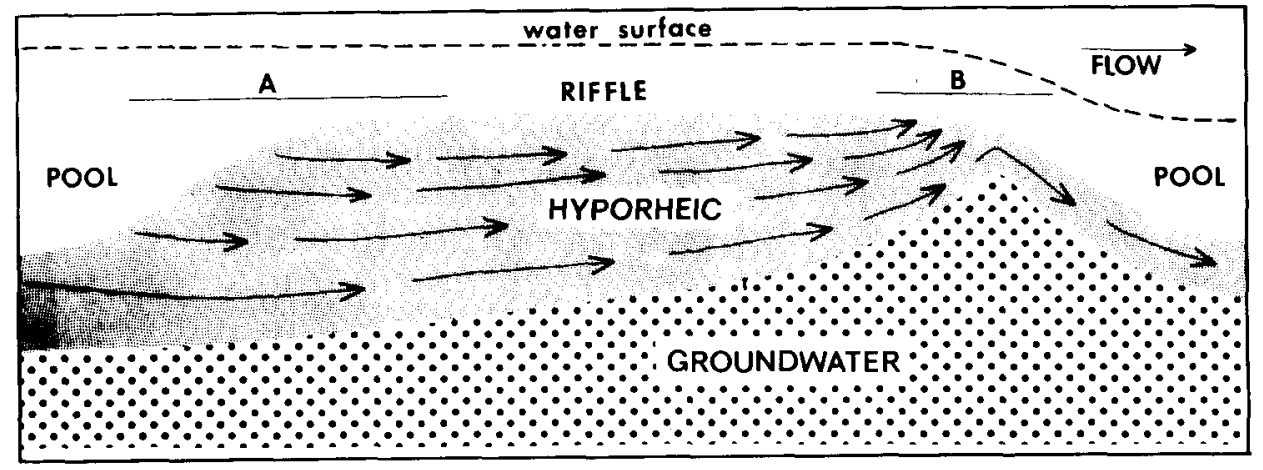

Fig. 1. Diagram of theoretical surface-water movement patterns (underflow) through the hyporheic zone of a streambed pool-riffle-pool sequence and the relation to groundwater distribution. Line $A$ represents the region of surface-water infiltration, and Line $B$ represents the region of underflow return to the surface (after Vaux, 1968; Thibodeaux and Boyle, 1987; White et al., 1987). 
Brater (1959)), bank seeps where the water table slopes toward the stream (Bardach, 1964), or stream-bottom seeps which, in many streams, are found at the beginnings of pools as a consequence of returning underflow (Bilby, 1984; White et al., 1987).

One of the simplest methods of locating surface-water infiltration, hyporheic water and groundwater areas is by measuring interstitial temperatures (Freeze and Cherry, 1979; White et al,. 1987), especially in warm-water streams in the summertime. Groundwater tends to remain near the mean annual temperature throughout the year (Freeze and Cherry, 1979), and, in northern Michigan, differences of nearly $20^{\circ} \mathrm{C}$ between surface water and groundwater are common.

Infiltrating surface water, underflow and groundwater seepage combine to form complex interstitial patterns along any reach of stream, particularly where riffle-pool sequences are well-developed. If macrophyte species have become adapted to utilizing some of the physicochemical properties of a particular type of interstitial water, then correlations with water type and distribution or abundance may be possible. Of particular interest in this study were species of Potamogeton which co-occur in many northern Michigan streams, in beds often separated by only a few meters and with no detectable differences in surface flow, depth, light or substratum type.

The objective of this study was to examine the types of interstitial water (based on temperature) occurring beneath 3 species of Potamogeton and beneath other common lotic macrophytes found in 3 northern Michigan (U.S.A.) streams. While the focus was on submerged taxa associated with flowing water, some lotic emergent and littoral taxa were examined as well.

\section{STUDY SITES}

This study was conducted in 3 similar-sized streams in northern Michigan, U.S.A. (Fig. 2). Lands surrounding all 3 sites contain primarily second-growth aspen (Populus tremuloides Michx. and P. grandidentata Michx.) with some northern hardwoods and mixed conifers. Soils in the area are sorted and unsorted glacial till up to 100 -m deep, permitting unconfined groundwater movement. The first site was on the East Branch of the Maple River, a 5-10-m wide third- to fourth-order stream originating as outflow from Douglas Lake. Midsummer stream temperatures $\left(22-27^{\circ} \mathrm{C}\right)$ reflected surface-water temperatures of Douglas Lake. Discharge was $0.51 \mathrm{~m}^{3} \mathrm{~s}^{-1}$ in mid-June and $0.36 \mathrm{~m}^{3} \mathrm{~s}^{-1}$ in mid-August. The second site was on the West Branch of the Maple River, a 4-10-m wide third- to fourth-order stream originating in a large white-cedar (Thuja occidentalis L.) swamp. Mid-summer temperatures in the study site reflected the groundwater origin, ranging from 18 to $22^{\circ} \mathrm{C}$. Discharge was 0.65 $\mathrm{m}^{3} \mathrm{~s}^{-1}$ in mid-June and $0.46 \mathrm{~m}^{3} \mathrm{~s}^{-1}$ in mid-August. Both the East and West Branches contain shallow riffles less than 0.5-m deep alternating with pools 


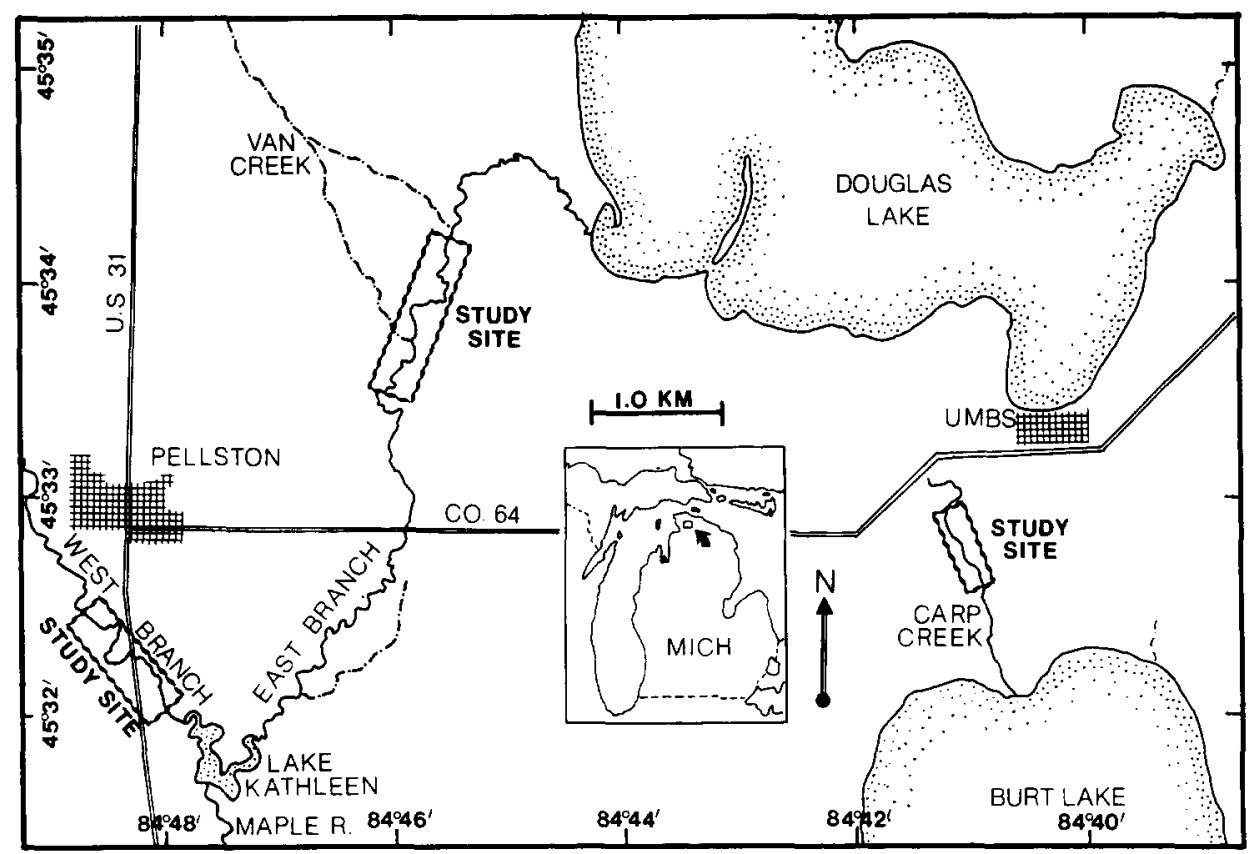

Fig. 2. Map of the study sites near the University of Michigan Biological Station (UMBS). Insert shows approximate location of study area in northern Michigan (U.S.A.).

up to 2.5-m deep. The streambed substrata in the East and West Branches vary from sand to gravel to cobble in the riffles and fast-flowing reaches, to sand with some accumulations of silt in the pools.

The third site was on Carp Creek, a 3-8-m wide first-order stream less than 3 -km long fed by several hundred groundwater springs. The source of the springs is Douglas Lake surface and epilimnetic water. The springs create nearly constant year-round temperatures $\left(10-12^{\circ} \mathrm{C}\right)$ and discharge $\left(0.34-0.40 \mathrm{~m}^{3} \mathrm{~s}^{-1}\right)$ (Pringle, 1985). The bed of Carp Creek is primarily sand with little riffle-pool development. Mid-summer temperatures measured at 9 flowing springs in the Carp Creek basin averaged $11.5^{\circ} \mathrm{C}(\mathrm{s} . \mathrm{d} .=1.2)$, approximately the mean annual air and Douglas Lake temperatures. Temperatures recorded from a 2-m deep well near the East Branch were slightly lower at $9.1^{\circ} \mathrm{C}($ s.d. $=1.30)$.

Study sites in the West and East Branches were not heavily shaded, and cover was estimated to be less than $30 \%$ (Table 1). While there were some open areas on Carp Creek, most of the study site was shaded with cover greater than $80 \%$. Shading, however, was not taken into account in the selection of plants to be analyzed.

Selected mid-summer physicochemical parameters for each stream and for a groundwater well are summarized in Table 1. The East and West Branches were similar except that the West Branch tended to have lower temperatures 


\section{TABLE 1}

Mid-summer physicochemical characteristics of surface water at each study site and at a groundwater well near East Branch of Maple River. Data summarized from our measurements and from unpublished University of Michigan Biological Station records, 1982-1984; standard deviations in parentheses

\begin{tabular}{|c|c|c|c|c|}
\hline & \multicolumn{3}{|l|}{ Surface water } & \multirow{2}{*}{$\begin{array}{l}\text { Groundwater } \\
(n=5)\end{array}$} \\
\hline & $\begin{array}{l}\text { East Branch } \\
\text { Maple River } \\
(n=6)\end{array}$ & $\begin{array}{l}\text { West Branch } \\
\text { Maple River } \\
(n=5)\end{array}$ & $\begin{array}{l}\text { Carp Creek } \\
(n=5)\end{array}$ & \\
\hline Temperature $\left({ }^{\circ} \mathrm{C}\right)$ & $24.5(1.9)$ & $19.8(1.6)$ & $11.4(0.9)$ & $9.1(1.3)$ \\
\hline $\begin{array}{l}\text { Carbonate alkalinity } \\
\left(\mathrm{mg} \mathrm{l}^{-1}\right)\end{array}$ & 140 & $150 \quad(5.0)$ & $165 \quad(3.5)$ & $220 \quad(6.8)$ \\
\hline 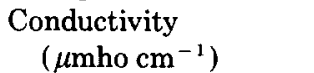 & $230 \quad(7.1)$ & $250 \quad(7.1)$ & 330 & $320 \quad(5.2)$ \\
\hline $\mathrm{Si}\left(\mathrm{mg} \mathrm{l}^{-1}\right)$ & $2.8(0.2)$ & $1.2(0.1)$ & $2.9(0.2)$ & $1.0(0.1)$ \\
\hline $\mathrm{PO}_{4}-\mathrm{P}\left(\mu \mathrm{gl}^{-1}\right)$ & $3.3(0.2)$ & $4.0(0.3)$ & $4.0(0.1)$ & $2.7(0.3)$ \\
\hline $\mathrm{NO}_{3}-\mathrm{N}\left(\mu \mathrm{gl}^{-1}\right)$ & $9.1(2.7)$ & $22.5(2.2)$ & $35.2(4.0)$ & $12.0(2.1)$ \\
\hline Chloride $\left(\mathrm{mg} \mathrm{l}^{-1}\right)$ & $3.6(0.1)$ & $4.5(0.3)$ & $2.4(0.1)$ & $1.4(0.1)$ \\
\hline $\begin{array}{l}\text { Dissolved oxygen } \\
\text { (\% Sat) } \\
\mathrm{pH} \text { (range) }\end{array}$ & $\begin{array}{l}100 \\
7.8-8.0\end{array}$ & $\begin{array}{l}100 \\
7.0-7.4\end{array}$ & $\begin{array}{l}100 \\
7.9-8.3\end{array}$ & $\begin{array}{l}<0.5 \\
\quad 6.6-6.8\end{array}$ \\
\hline $\begin{array}{l}\text { Estimated percentage } \\
\text { cover }\end{array}$ & $<30$ & $<30$ & $>80$ & \\
\hline $\begin{array}{l}\text { Estimated mean width } \\
(\mathrm{m})\end{array}$ & 7 & 8 & 6 & \\
\hline Maximum depth (m) & 2.5 & 2.5 & 1.5 & \\
\hline $\begin{array}{l}\text { Discharge } \\
\quad\left(\mathrm{m}^{3} \mathrm{~s}^{-1}\right)(n=2)\end{array}$ & $0.36-0.51$ & $0.46-0.63$ & $0.36-0.37$ & \\
\hline
\end{tabular}

and $\mathrm{pH}$ and more inorganic nitrogen. Nutrient levels in the East Branch reflected surface water characteristics of Douglas Lake which become quite low in inorganic nitrogen in late summer (R. Glover, personal communication, 1986). Carp Creek differed from the other sites in higher conductivity and inorganic nitrogen and much lower temperatures. Groundwater from the well differed from the East Branch site in lower temperatures, dissolved oxygen and $\mathrm{pH}$ and in much higher alkalinity and conductivity.

\section{MATERIALS AND METHODS}

Individual plants were sampled at random from distinct plant beds. No more than 2-3 individuals were examined in any one plant bed. For most species, about 40 plants per stream were sampled (Table 2 ). Interstitial water temperatures beneath each plant were measured to the nearest $0.5^{\circ} \mathrm{C}$ at the streambed 
TABLE 2

Numbers of emergent $(\mathrm{E})$ and submerged $(\mathrm{S})$ aquatic vascular macrophytes examined in the East Branch of Maple River (EBMR), West Branch of Maple River (WBMR), and Carp Creek, $\mathrm{NP}=$ not present. Mean surface-water velocity and standard deviation $\left(\mathrm{cm} \mathrm{s}^{-1}\right)$ based on measurements taken in mid-bed; $n=20$ ( 10 from measurements from each stream combined if present in more than one stream)

\begin{tabular}{|c|c|c|c|c|c|}
\hline \multirow[t]{2}{*}{ Taxon } & \multicolumn{4}{|c|}{ Distribution } & \multirow{2}{*}{$\begin{array}{l}\text { Velocity } \\
\left(\mathrm{cm} \mathrm{s}^{-1}\right) \\
\text { (s.d.) }\end{array}$} \\
\hline & Form & EBMR & WBMR & $\begin{array}{l}\text { Carp } \\
\text { Creek }\end{array}$ & \\
\hline \multicolumn{6}{|l|}{ Sparganiaceae } \\
\hline $\begin{array}{l}\text { Sparganium chlorocarpum Rydb. } \\
\text { Potamogetonaceae }\end{array}$ & $\mathrm{S}$ & 41 & 40 & Potamogetonaceae & $32(8.2)$ \\
\hline Potamogeton filiformis Pers. & $\mathrm{S}$ & 41 & 40 & NP & $51(6.7)$ \\
\hline P. gramineus L. & $\mathrm{S}$ & 102 & NP & NP & $46(8.2)$ \\
\hline P. richardsonii (Benn.) Rydb. & $\mathrm{S}$ & 104 & 40 & NP & $43(7.3)$ \\
\hline Alismaceae & & & & & \\
\hline Sagittaria latifolia Willd. & $\mathbf{E}$ & 40 & 40 & NP & $<10$ \\
\hline \multicolumn{6}{|l|}{ Ranunculaceae } \\
\hline Ranunculus septentrionalis Poir. & $\mathbf{E}$ & NP & NP & 40 & $<10$ \\
\hline Caltha palustris L. & $\mathrm{E}$ & NP & NP & 40 & $<10$ \\
\hline \multicolumn{6}{|l|}{ Cruciferae } \\
\hline Nasturtium officinale R.Br. & $\mathbf{E}$ & NP & 40 & 40 & $<10$ \\
\hline \multicolumn{6}{|l|}{ Scrophulariaceae } \\
\hline Veronica catenata Penn. & $\mathrm{S}$ & 38 & 40 & NP & $22(7.5)$ \\
\hline
\end{tabular}

surface and at depths of $5,10,15,20,30,40$ and $50 \mathrm{~cm}$ into the bed using a 95$\mathrm{cm}$ long stainless-steel temperature probe and thermister (YSI series 400).

Surface-water velocity was measured in 20 beds of each species. If a species occurred in more than one stream, 10 beds were selected from each stream. At least 3 velocity measurements were taken in the center of each plant bed using a Pygmy-Gurley flow meter positioned at $60 \%$ of stream depth. Velocity estimates in flows less than $10 \mathrm{~cm} \mathrm{~s}^{-1}$ were highly variable using the PygmyGurley and were recorded only as $<10 \mathrm{~cm} \mathrm{~s}^{-1}$.

To examine the differences between the species further, we attempted to measure root-penetration depths using a $10-\mathrm{cm}$ diameter mechanical corer. Data are discussed for only Potamogeton gramineus $\mathrm{L}$. and $P$. richardsonii (Benn.) Rydb., and these data must be considered preliminary because biomass was not taken into account, the depths of some of the smaller roots and root hairs may have been missed, and there were problems removing intact cores from sand-gravel substrata. Few roots of any species, however, appeared to penetrate much deeper than $15 \mathrm{~cm}$. Therefore, analyses were based primarily on interstitial temperatures at the $10-\mathrm{cm}$ depth interval. To determine if interstitial temperatures at $10-\mathrm{cm}$ deep were significantly different between 
species, data were analyzed by analysis of variance using the Statistical Analysis System (SAS). Significance levels were set at $\alpha=0.05$. Plots of the number of individuals versus temperature at $10-\mathrm{cm}$ deep for each species appeared Gaussian; therefore, for additional comparisons, the mean temperature and temperature range encompassing $95 \%$ of the distribution were estimated for each species using the Gaussian function given by Robbins et al. (1984).

Determining boundaries between infiltrating surface water, hyporheic water and groundwater is made somewhat more difficult by the thermal conductance produced from flow along the longitudinal gradient within the bed. For convenience, however, the hyporheic zone can be defined as some intermediate temperature range between surface water and groundwater over which surfacewater characteristics remain dominant (Williams, 1984). Interstitial water was determined to contain primarily surface-water infiltration if temperatures were higher than the minimum surface-water temperature recorded over any $24-\mathrm{h}$ period during the study time $\left(17.5^{\circ} \mathrm{C}\right.$ for the West Branch, $18.0^{\circ} \mathrm{C}$ for the East Branch, D.S. White, unpublished data, 1983-1985). A site was assumed to contain underflow if temperatures ranged between $13^{\circ} \mathrm{C}$ and the minimum surface water temperature. Unpublished mid-summer data (S.P. Hendricks, University of Michigan, 1984-1986; D.S. White, 1984-1986) showed that interstitial water warmer than $13^{\circ} \mathrm{C}$ usually contained dissolved-oxygen concentrations higher than $20 \%$ saturation and negligible free $\mathrm{CO}_{2}$. Interstitial water cooler than $13^{\circ} \mathrm{C}$ was considered to be primarily groundwater. At that temperature, dissolved-oxygen concentrations were usually less than $5 \%$ saturation, and free $\mathrm{CO}_{2}$ concentrations were often higher than $40 \mathrm{mg} \mathrm{l}^{-1}$.

\section{RESULTS AND DISCUSSION}

Nine species of aquatic macrophyres typical of northern Michigan streams (Fassett, 1969; Voss, 1972, 1985) were common and widespread in one or more of the 3 study sites (Table 2). No attempts were made, however, to determine overall relative abundances of any species. One species, Potamogeton gramineus, was limited to the East Branch; 5 species were common to the East and West Branches; one species, Nasturtium officinale R. Br., was common to the West Branch and Carp Creek. While Table 2 lists Ranunculus septentrionalis Poir. and Caltha palustris L. from only Carp Creek, we since have found a few isolated specimens of both species at bank seeps along the West Branch; however, no interstitial temperature measurements were made.

Sparganium chlorocarpum Rydb. and Veronica catenata Penn. were often found together near the stream margins at the beginnings of pools and just out of the fastest flows (Table 2). Substrata were firm, coarse sands mixed with gravel. Well-developed beds of the three species of Potamogeton were found only in the fastest flowing reaches (Table 2). P. filiformis Pers. and P. richardsonii usually were found together near the center of the stream at the down- 
stream end of riffles or beginnings of pools. Substrata were most often coarse gravels. Beds of $P$. gramineus were more scattered, occasionally occurring near beds of the other two Potamogeton species, but more often occurring near the head and mid-sections of the riffles. Substrata ranged from coarse sand to coarse gravel. Sagittaria latifolia Willd. was most common along the stream margins where there was little to no surface flow (Table 2). The top few $\mathrm{cm}$ of surface substrata were usually fine sand and silt grading deeper $(5-10 \mathrm{~cm})$ into very coarse gravel. Ranunculus septentrionalis and Caltha palustris usually occurred together along the stream margin in depositional areas with little to no surface flow (Table II) and near groundwater springs. Substrata were deep, fine sands. Nasturtium officinale beds also were located in sandy, depositional zones near the stream margin, but portions of the beds often extended into surface flows greater than $10 \mathrm{~cm} \mathrm{~s}^{-1}$. Most beds were found near groundwater seeps or springs.

For species examined in the East Branch, the mean interstitial temperatures at the $10-\mathrm{cm}$ depth were significantly higher beneath Potamogeton gramineus $\left(19.5^{\circ} \mathrm{C}\right)$ than beneath beds of other species $\left(14.6-16.2^{\circ} \mathrm{C}, \mathrm{Fig} .3\right)(P<0.001)$. There were no significant interstitial temperature differences among the remaining species; however interstitial temperatures beneath Veronica catenata showed a much greater range than occurred in other East Branch species. For plants in the West Branch, the mean interstitial temperature at the $10-\mathrm{cm}$ depth was significantly less beneath Nasturtium officinale $\left(12.1^{\circ} \mathrm{C}\right)$ than beneath the other 5 species $\left(14.8-16.0^{\circ} \mathrm{C}\right.$, Fig. 3$)(P<0.001)$, and again there were no significant interstitial temperature differences between the remaining species. Mean interstitial temperatures $10-\mathrm{cm}$ deep beneath plants from Carp Creek were nearly identical at approximately $11.5^{\circ} \mathrm{C}$ (Fig. 3) which reflected the narrow temperature range between surface water and interstitial water in this stream.

Interstitial temperature differences between populations of species occurring in both the East and West Branches were not significant $(P<0.001)$, but the temperature ranges were slightly broader for some East Branch populations, particularly for Veronica catenata (Fig. 3). Only Nasturtium officinale occurred in both the West Branch and Carp Creek. The mean interstitial temperatures at $10-\mathrm{cm}$ deep were not significantly different $(P<0.01)$ between populations, but again the range was slightly broader beneath plants in the warmer West Branch (Fig. 3).

When the distributions of Sparganium chlorocarpum, Sagittaria latifolia, Veronica catenata and the 3 species of Potamogeton were examined in relation to predicted interstitial water patterns beneath pool-riffle-pool sequences, all except $S$. latifolia and $P$. gramineus usually occurred in areas where underflow was expected to be returning to the surface (Segment B in Fig. 1). Although interstitial temperatures beneath $S$. latifolia were similar to several other species, the expected source (groundwater or underflow) was not determined. Beds 


\section{R. SEPTENTRIONALIS}
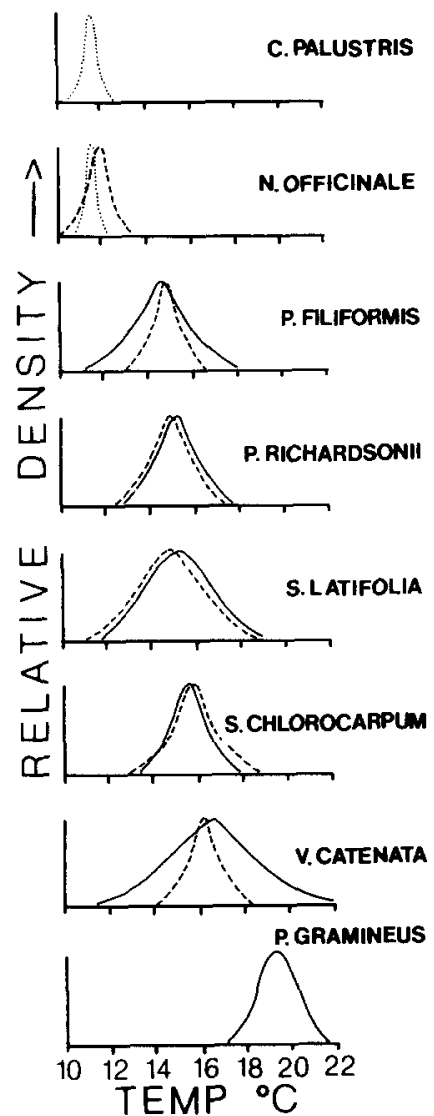

Fig. 3. Estimated distribution of each aquatic plant species in the East Branch of the Maple River (-), West Branch of the Maple River (-..), and Carp Creek (...) versus temperature 10-cm deep in the streambed. Lines represent Gaussian fits encompassing $95 \%$ of the calculated distribution for each species from the function described by Robbins et al. (1984).

of $P$. gramineus appeared to be more common only in areas of warm surfacewater infiltration (Segment A in Fig. 1).

Studies by Wallis et al. (1981), Bencala (1984) and Grimm and Fisher (1984) have shown that streambed sediments and interstitial water in underflow areas contain much higher concentrations of nutrients and ions than surface waters, and it has been speculated that concentrations may increase with distance along the underflow gradient. Initial studies of the interstitial chemistry of the East Branch (S.P. Hendricks, unpublished data, 1987; also see Hendricks and White, 1988) show that underflow 10-20-cm deep may contain up to 10 times 
more inorganic phosphorus $\left(\mathrm{PO}_{4}-\mathrm{P}\right)$ and 3 times more inorganic nitrogen $\left(\mathrm{NO}_{3}-\mathrm{N}\right)$ than surface water. $\mathrm{N}: \mathrm{P}$ ratios also differed from 12.5:1 in surface water to $3.4: 1$ in underflow.

Although comparatively little is known of the biology of the studied species, uptake experiments have demonstrated that roots of many lentic taxa can absorb nutrients, ions and gases directly from sediments/interstitial water (Denny, 1972; Barko and Smart, 1980, 1981; Smith and Adams, 1986). Some species, including Potamogeton pectinatus L. (Huebert and Gorham, 1983), are able to meet all requirements for nitrogen $\left(\mathrm{NO}_{3}-\mathrm{N}\right)$ and phosphorus $\left(\mathrm{PO}_{4}^{-}\right.$ P) from the sediments (Best and Mantai, 1978) which led Carignan and Kalff (1980) to characterize aquatic macrophytes as conveyor mechanisms for the transfer of nutrients between sediments and open water.

Potamogeton gramineus is morphologically quite similar to $P$. richardsonii except that $P$. gramineus possesses large stipules which may serve as sites of nutrient uptake from surface waters (Denny, 1972). Further, $P$. richardsonii has been shown to obtain sufficient quantities of sodium (Haslam, 1978), copper and zinc (Cushing and Thomas, 1980) from the sediments to meet plant requirements. $P$. richardsonii and $P$. gramineus also appeared to differ in rootpenetration depth. Mean root depths were $14.2 \mathrm{~cm}( \pm 3.35$, range $10-22 \mathrm{~cm}$, $n=40)$ for $P$. richardsonii and $8.7 \mathrm{~cm}( \pm 2.85$, range $4-14 \mathrm{~cm}, n=35)$ for $P$. gramineus. Without experimental evidence from uptake studies and more extensive water column/sediment chemistry data, we cannot confirm that $P$. gramineus relies more on surface waters for nutrients, ions, etc., while $P$. richardsonii and other studied species rely on interstitial sources for one or more of these plant requirements.

In summary, Ranunculus septentrionalis, Caltha palustris and Nasturtium officinale were found where the interstitial water was primarily groundwater discharge. Sparganium chlorocarpum, Veronica catenata, Potamogeton filifor$m i s$ and $P$. richardsonii were most common where the interstitial water was expected to be surface water that had passed through the streambed (underflow ) and was returning to the surface. $P$. gramineus was more widely distributed along the riffles but was limited to warm interstitial temperatures in suspected areas of surface-water infiltration into the streambed. Infiltration, underflow and groundwater form complex interstitial patterns, particularly in third to fourth order streams with well-developed riffle-pool sequences. Differences in interstitial water temperature, nutrients, ions, etc., combined with differences in plant requirements and uptake sites may be important in establishing local distributions of lotic aquatic vascular macrophytes.

\section{ACKNOWLEDGEMENTS}

We wish to thank C. Barre Hellquist for confirming identifications of the plant species. T. Keilty, C. Elzinga and S. Hendricks assisted with the field 
work and made valuable comments throughout the study and the production of the manuscript. Our appreciation is extended to the University of Michigan Biological Station for providing laboratory space, equipment, and an atmosphere conducive to scientific research.

Contribution No. 480 from the Great Lakes Research Division, University of Michigan.

\section{REFERENCES}

Bardach, J., 1964. Downstream, A Natural History of the River. Harper and Row, New York, 278 pp.

Barko, J.W. and Smart, R.M., 1980. Mobilization of sediment phosphorus by submersed freshwater macrophytes. Freshwater Biol., 10: 229-238.

Barko, J.W. and Smart, R.M., 1981. Sediment based nutrition of submerged macrophytes. Aquat. Bot., 10: 339-352.

Beal, E.O., 1977. A Manual of Marsh and Aquatic Vascular Plants of North Carolina, with Habitat Data. North Carolina Agric. Exp. Stn., 298 pp.

Bencala, K.E., 1984. Interactions of solutes and streambed sediment 2. A dynamic analysis of coupled hydrologic and chemical processes that determine solute transport. Water Resour. Res., 20: 1075-1080.

Best, M.D. and Mantai, K.E., 1978. Growth of Myriophyllum: sediment or lake water as the source of nitrogen and phosphorus? Ecology, 59: 1075-1080.

Bilby, R.E., 1984. Characteristics and frequency of cool-water areas in a western Washington stream. J. Freshwater Ecol., 2: 593-602.

Carignan, R. and Kalff, J., 1980. Phosphorus sources for aquatic weeds: water or sediments? Science, 207: 987-989.

Correll, D.S. and Correll, H.B., 1972. Aquatic and Wetland Plants of Southwestern United States. Water Pollut. Control Res. Ser. 16030 DNL 01/72, 1777 pp.

Cushing, E.E and Thomas, J.M., 1980. Cu and Zn kinetics in Myriophyllum heterophyllum Michx and Potamogeton richardsonii (A.R. Benn.) Rydb. Ecology, 61: 1321-1326.

Denny, P., 1972. Sites of nutrient absorption in aquatic macrophytes. J. Ecol., 60: 819-829.

Fassett, N.C., 1969. A Manual of Aquatic Plants. Univ. Wisconsin Press, 405 pp.

Freeze, R.A. and Cherry, J.A., 1979. Groundwater. Prentice-Hall, Englewood Cliffs, New Jersey, $604 \mathrm{pp}$.

Gray, J.L., Ward, J.V., Martinson, R. and Bergey, E., 1983. Aquatic macroinvertebrates of the Piceance Basin, Colorado: community response along spatial and temporal gradients of environmental conditions. Southwest. Nat., 28: 125-135.

Grimm, N.B. and Fisher, S.G., 1984. Exchange between interstitial and surface water: implications for stream metabolism and nutrient cycling. Hydrobiologia, 111: 219-228.

Haslam, S.M., 1978. River Plants: The Macrophytic Vegetation of Watercourses. Cambridge Univ. Press, $396 \mathrm{pp}$.

Hendricks, S.P. and White, D.S., 1988. Hummocking by lotic Chara: observations on alterations of hyporheic temperature patterns. Aquat. Bot., 31: 13-22.

Huebert, D.B. and Gorham, P.R., 1983. Biphasic mineral nutrition of the submersed aquatic macrophyte Potamogeton pectinatus L. Aquat. Bot., 16: 269-284.

Hutchinson, G.E., 1975. A Treatise on Limnology. Vol. III. Limnological Botany. John Wiley and Sons, N.Y., 660 pp. 
Kullberg, R.G., 1974. Distribution of aquatic macrophytes related to paper mill effluents in a southern Michigan stream. Am. Midl. Nat., 91: 271-281.

Muenscher, W.C., 1944. Aquatic Plants of the United States. Cornell Univ. Press, 374 pp.

Peltier, W.H. and Welch, E.B., 1968. Factors affecting growth of rooted aquatics in a river. Weed Sci., 17: 412-416.

Pringle, C.M., 1985. Nutrient heterogeneity and the maintenance of species diversity: periphyton response to substratum and water enrichment in a nutrient-poor stream. Doctoral thesis, University of Michigan, Ann Arbor, MI, 150 pp.

Robbins, J.A., Husby-Coupland, K. and White, D.S., 1984. Precise radiotracer measurement of the rate of sediment reworking by Stylodrilus heringianus and the effects of variable dissolved oxygen concentrations J. Great Lakes Res., 10: 335-347.

Smith, C.S. and Adams, M.S., 1986. Phosphorus transfer from sediments by Myriophyllum spicatum. Limnol. Oceanogr., 31: 1312-1321.

Spence, H.H.N., 1967. Factors controlling the distribution of freshwater macrophytes with particular reference to the Lochs of Scotland. J. Ecol., 55: 147-169.

Thibodeaux, L.J. and Boyle, J.D., 1987. Bedform-generated convective transport in bottom sediments. Nature (London), 325: 341-343.

Vaux, W.G., 1968. Intergravel flow and interchange of water in a streambed. Fish. Bull., 66: 479489.

Voss, E.G., 1972. Michigan Flora. Part I. Gymnosperms and Monocots. Cranbrook Institute of Science, Bloomfield Hills, Michigan, Bull. 55, 488 pp.

Voss, E.G., 1985. Michigan Flora. Part II. Dicots (Saururaceae-Cornaceae). Cranbrook Institute of Science, Bloomfield Hills, Michigan, Bull. 59. $724 \mathrm{pp}$.

Wallis, P.M., Hynes, H.B.N. and Telang, S.A., 1981. The importance of groundwater in the transportation of allochthonous dissolved organic matter to the streams draining a small mountain basin. Hydrobiologia, 79: 77-90.

White, D.S., Elzinga, C.H. and Hendricks, S.P., 1987. Temperature patterns within the hyporheic zone of a northern Michigan stream. J. N. Am. Benthol. Soc., 6: 85-91.

Williams, D.D., 1984. The hyporheic zone as a habitat for aquatic insects and associated arthropods. In: V.H. Resh and D.M. Rosenberg (Editors), The Ecology of Aquatic Insects. Praeger, New York, $625 \mathrm{pp}$.

Wisler, C.O. and Brater, E.F., 1959. Hydrology. J. Wiley and Sons, New York, 408 pp. 